\title{
MINAT SISWI SLTP TERHADAP PERMAINAN SEPAK BOLA WANITA DI SSB QUEEN KOTA BANDUNG
}

\section{INTEREST OF WOMEN JUNIOR HIGH SCHOOL STUDENT'S IN SOCCER AT SSB QUEEN BANDUNG}

\author{
Papat Yunisial \\ Dosen STKIP Cimahi \\ E-mail: papat_yunisal@yahoo.com
}

\begin{abstract}
ABSTRAK
Penelitian ini bertujuan untuk mengetahui gambaran minat siswi SLTP terhadap permainan sepak bola di Kota Bandung. Jenis penelitian ini adalah penelitian deskriktif. Populasi dalam penelitian ini adalah siswi SLTP di Kota Bandung yang aktif mengikuti latihan sepak bola di klub Putri Priangan Kota Bandung. Dan yang menjadi sampel penelitian, sebanyak 30 orang. Teknik pengumpulan data dalam penelitian ini adalah dengan angket, Teknik analisa data menggunakan uji rata-rata. Hasil penelitian menunjukkan sub komponen valuing mempunyai dukungan terbesar terhadap terbentu-knya minat, dengan besar dukungan $35.35 \%$, kemudian peringkat kedua adalah sub komponen receiving sebesar 33.03\%, sedangkan dukungan terkecil sub komponen responding dengan dukungan sebesar 31.62\%.Faktor-faktor yang mempengaruhi minat siswi SLTP terhadap permainan sepak bola di Kota Bandung adalah, pertama lingkungan 18.38\%, kedua diri pribadi 18.03\%, ketiga adalah guru / pelatih dan sarana/ prasarana $16,86 \%$, selanjutnya adalah teman $16.35 \%$, dan yang terakhir adalah faktor program dengan besar dukungan $13.52 \%$.
\end{abstract}

Kata kunci : Minat, Permainan Sepak Bola.

\section{ABSTRACT}

This research aimed to understand junior high school students' interest towards Bandung 's football. The population of this descriptive reseach were 30 junior high school students who actively involved in Putri Periangan Kota Bandung Football Club. It used questionnaire as its data collection technique and t-test for its data analysis. The study showed that sub-component valuing was the biggest contributor in building students' interest in Football(35.35\%), then the second was sub-component receiving (33.03\%), while the least came from subcomponent responding with the support percentage of $31.62 \%$. The factors that influenced their interest were as followed: environment (18.38\%), personal reason (18.03\%), teachers / coach and facilities (16, $86 \%)$, friends (16,35\%), and finally, the program itself $(13,52 \%)$.

Keyword: Interest, Soccer Games

\section{PENDAHULUAN}

Permainan sepak bola merupakan salah satu cabang olahraga yang sangat diminati oleh semua kalangan masyarakat, mulai dari kalangan anak-anak sampai orang dewasa, baik laki-laki maupun wanita, masyarakat kalangan bawah maupun atas yang ada didunia, termasuk di Indonesia (Treanor, Graber,Housner, \& Wiegand, 2015). Permainan ini merupakan permainan yang dilakukan oleh dua regu, dimana tujuan dari permainan ini adalahuntukmemasukan bolake dalam gawang regu lawan (Lirgg, 2013). Menurut Irianto (2012:3) mengatakan "Sepakbola adalah permainan dengan cara menendang sebuah bola yang diperebutkan oleh para pemain dari dua kesebelasan yang berbeda dengan bermaksud memasukan bola ke gawang lawan dan mempertahankan gawang sendiri jangan sampai kemasukan bola".

Permainan sepak bola ini merupakan suatu bentuk permainan yang cukup banyak teknik dasarnya. Sebagaimana yang dikatakan oleh Herwin (2016:78) bahwa: "Permainan sepakbola merupakan permainan kelompok yang melibatkan banyak unsur, seperti fisik, teknik, taktik, dan mental". Banyaknya unsur yang harus dikuasai oleh para pemain, mendorong para pelatih untuk terus berupaya meningkatkan kualitas performa atletnya, mulai dari melakukan pendekatan secara fisiologis, sosiologis, maupun psikologis (Chepyator-Thomson \& Ennis, 2017).

Upaya peningkatan prestasi olahraga perlu 
dilaksanakan melalui pembinaan olahraga sedini mungkin dengan cara pencarian dan pemantauan bakat, pembibitan, pendidikan dan pelatihan olahraga prestasi yang didasarkan pada ilmu pengetahuan dan teknologi secara efektif dan efisien serta peningkatan kualitas organisasi keolahragaan baik di daerah maupun di pusat (Ady, 2016). Disamping penyediaan sarana dan prasarana olahraga yang memadai, yang dilaksanakan pemerintah maupun peran serta masyarakat, perlu ditingkatkan supaya pembibitan olahragawan dan pembinaan olahraga dapat lebih meningkat dan merata di seluruh pelosok tanah air serta mencakup segenap kelompok umur (Linda Rikard \& Banville, 2016).

Sebagaimana kita ketahui, bahwa permainan sepak bola dewasa ini tidak hanya milik kaum laki-lakiu saja, seiring dengan perkembangan nilai-nilai olahraga permainan sepak bola pun sudah banyak dimainkan oleh kaum perempuan, hal ini terbukti dengan bayak berdirinya klub-klub sepak bola putri, seperti : Buana Putri Jakarta, Putri Priangan, Perses putri Sumedang, Putri Dafonsoro. Bahkan pemerintah sudah memberikan perhatian dengan menggelar kejuaraan berupa Turnamen Sepak Bola Putri Indoensia. Hal ini membuktikan bahwa minat kaum perempuan terhadap permainan sepak bola sudah mulai meningkat, dan hal ini juga yang merangsang para pelaku olahraga sepak bola, mulai dari pemain, pelatih, pembina juga pemerintah ingin meningkatkan kualitas permainan sepak bola wanita di Indonesia, sehingga banyak upaya yang dilakukan baik dalam sektor pembinaan, pelatihan, dan juga penyediaan sarana dan prasarananya (Markovits \& Hellerman, 2013; Rustanto \& Rustanto, 2013).

Khususnya dalam sektor pelatihan dan pembinaan, upaya untuk memaksimalkan penampilan atlet, pembina olahraga atau pelatih perlu memahami dan menguasai kajian psikologi olahraga. Salah satu kajian psikologi olahraga adalah mempelajari tentang tingkah laku dan pengalaman manusia dalam berolahraga (Kokoti, Pomatahu, 2015). Dampak olahraga terhadap individu yang satu dengan yang lainnya berbeda, hal ini tergantung dan disebabkan karena sifatsifat individual yang berbeda. Bakat, minat, dan motif-motif yang berbeda menyebabkan individu yang satu memilih salah satu cabang olahraga berbeda dengan yang lainnya (Dewandaru, 2012).

Salah satu bentuk pendekatan secara psikologis yang dikenakan pada atlet pemula adalah dengan mengetahui minat siswa/atlet terhadap cabang olahraga yang ditekuninya. Minat merupakan sumber motivasi yang kuat dalam mendorong seseorang untuk belajar. (Hurlock, 2013:114) menjelaskan bahwa minat menjadi sumber motivasi yang kuat untuk belajar. Anak berminat terhadap sebuah kegiatan baik permainan maupun pekerjaan, akan berusaha lebih keras untuk belajar dibandingkan dengan anak yang kurang berminat atau meras bosan. pengalaman belajar merupakan kemampuan anak sepenuhnya, rangsangan harus diatur supaya bertepatan dengan minat. Ini merupakan "saat siap belajar" (Pamungkas, 2016).

Surya (2012:99) menjelaskan, bahwa minat dapat dikategorikan menjadi tiga macam yaitu (1) Minat volunter, (2) Minat involunter, dan (3) Minat nonvolunter. Minat volunter ialah minat yang timbul secara sukarela, dari diri siswa tanpa adanya pengaruh dari luar. Minat involunter ialah minat yang timbul dari siswa dengan pengaruh situasi yang diciptakan oleh pengajar. Minat nonvolunter ialah minat yang timbul dari diri siswa secara dipaksa atau diharuskan (Hidayat Nur, 2016).

Selanjutnya Irwanto. (2014:143) mengungkapkan bahwa "Minat merupakan momen dari kecenderungan yang terarah secara intensif kepada suatu objek yang dianggap penting”. Tinjauan terhadap suatu minat atau perhatian pada suatu bidang merupakan suatu hal yang sulit dan komplek karena banyak aspek yang harus diteliti, serta banyaknya ragam minat yang dimiliki dan 
banyaknya cabang olahraga yang ditawarkan pada siswa di sekolah.

Daripenjelasan diatas, penulis berpendapat bahwa minat dapat mendorong seseorang untuk berusaha lebih giat dalam belajar, karena itu minat merupakan perangsang bagi setiap individu yang belajar (Permadi, 2016). Jadi keberhasilan seseorang dalam belajar salah satunya ditentukan oleh tinggi rendahnya minat yang dimiliki. Peranan guru atau pelatih di klub sepak bola ataupun keikut sertaan peserta didik dalam menekuni cabang olahraga sepak bola khusunya, perlu ditindak lanjuti dengan pemahaman psikis anak itu dalam mengikutinya (B \& Subiyono, 2015). Hal ini tidak lain supaya guru/pelatih dapat mengetahui sejauhmana minat siswa terhadap prestasi cabang olahraga yang ditekuninya, misalnya permainan sepak bola (Griffin, 2014).

Dari permasalahan di atas, penulis merasa tertarik untuk mengetahui seberapa besar minat siswi SLTP di Kota Bandung terhadap permainan sepak bola, sehingga diharapkan nantinya penelitian ini dapat dimanfaatkan sebagai bahan informasi (input) bagi lembaga pendidikan sekolah lanjutan dan klub-klub sepak bola putri dalam usaha meningkatkan prestasi.

\section{METODE PENELITIAN}

Metode yang digunakan dalam penelitian ini adalah metode deskriptif. Menurut Riyanto dalam (Komara, 2012:101) mengatakan bahwa penelitian deskriptif adalah penelitian yang diarahkan untuk memberikan gejalagejala, fakta-fakta atau kejadian-kejadian secara sistematis dan akurat, mengenai sifatsifat populasi atau daerah tertntu.

Populasi dalam penelitian ini adalah siswi SLTP di Kota Bandung yang aktif mengikuti latihan sepak bola di klub Putri Priangan Kota Bandung. Dan yang menjadi sampel penelitiannya sebanyak 30 orang dengan teknik pengambilan sampel melalui teknik random sampling. Instrumen yang digunakan adalah berupa angket tertutup atau angket berstruktur. Pengolahan dan analisis data dilakukan dengan dua tahapan, pertama melakukan seleksi data dan tahap kedua penskoran data.

\section{HASIL PENELITIAN DAN \\ PEMBAHASAN}

\section{Hasil Perhitungan Validasi Instrumen}

Berdasarkan hasil analisis validitasnya ternyata instrumen minat siswa yang dianggap valid sebanyak 15 butir dan sembilan butir pernyataan dianggap tidak valid atau tidak layak untuk digunakan sebagai instrumen, untuk itu penulis merevisi kesembilan instrumen tersebut supaya layak untuk digunakan sebagai instrumen penelitian. Berikut data instrumen yang valid dan tidak valid penulis tuangkan dalam tabel 1 .

Selanjutnya setelah ditentukan validitas butir soal, kemudian dilanjutkan dengan analisis reliabilitas instrumen, rumus yang digunakan adalah split half. Hasil penghitungan dan analisis reliabilitas butirbutir pernyataan menunjukkan besarnya koefisien korelasi setengah tes adalah (Rxy) sebesar 0.62 sedangkan besarnya koefisien korelasi seluruh tes $\left(\mathrm{r}_{\mathrm{n}}\right)$ adalah 0.77, selanjutnya dibandingkan dengan $\mathrm{t}$ tabel (0.975:28) sebesar 2.05, dapat dinyatakan besarnya koefisien korelasi tersebut adalah signifikan.

\section{Menentukan Taraf Serap Dan Rangking.}

Penentuan taraf serap dimaksudkan untuk mengetahui sub komponen pernyataan yang mana yang mempunyai prosentase dan rangking terbesar, pada masing-masing sub komponen berdasarkan indikator. Adapun rumus yang digunakan untuk menentukan taraf serap ialah sebagai berikut:

$$
\mathrm{TS}=\frac{\mathrm{Sf}}{\mathrm{Sm}} \times 100 \%
$$

Berdasarkan tabel 2, pada sub komponen responding pernyataan nomor 4 mempunyai taraf serap terbesar dengan $15.43 \%$, sedangkan taraf serap terkecil ditempati 
Tabel 1

Hasil Penghitungan Instrumen Minat Siswi SLTP terhadap Permainan Sepak bola di Kota Bandung

\begin{tabular}{|c|c|c|}
\hline No. Soal & t Hitung & Keterangan \\
\hline & 3.85 & Valid \\
\hline & 1.31 & Tidak valid \\
\hline & 0.61 & Tidak valid \\
\hline & 4.32 & Valid \\
\hline & 14.70 & Valid \\
\hline & 2.02 & Valid \\
\hline & 2.72 & Valid \\
\hline & 1.27 & Tidak valid \\
\hline & 11.20 & Valid \\
\hline & 2.36 & Valid \\
\hline & 6.67 & Valid \\
\hline & 2.21 & Valid \\
\hline & 8.31 & Valid \\
\hline & 4.13 & Valid \\
\hline & 3.85 & Valid \\
\hline & 3.15 & Valid \\
\hline & 0.09 & Tidak valid \\
\hline & 2.25 & Valid \\
\hline & 1.27 & Tidak valid \\
\hline & 5.49 & Valid \\
\hline & 0.56 & Tidak valid \\
\hline & 0.09 & Tidak valid \\
\hline & 1.97 & Tidak valid \\
\hline & 1.98 & Tidak valid \\
\hline
\end{tabular}

Tabel 2

Taraf Seraf dan Rangking Jawaban Butir Pertanyaan Komponen Responding

\begin{tabular}{cccc}
\hline No. Soal & Skor faktual & $\begin{array}{c}\text { Taraf serap } \\
\text { (prosentase) }\end{array}$ & Rangking \\
\hline 4 & 126 & $15.43 \%$ & 1 \\
\hline 1 & 124 & $15.17 \%$ & 2 \\
\hline 23 & 116 & $14.20 \%$ & 3 \\
\hline 3 & 105 & $12.85 \%$ & 4 \\
\hline 2 & 102 & $12.48 \%$ & 5 \\
\hline 24 & 100 & $12.24 \%$ & 7 \\
\hline 6 & 99 & $12.12 \%$ & 8 \\
\hline 5 & 45 & $5.51 \%$ & \\
\hline Jumlah & 817 & $100 \%$ & \\
\hline
\end{tabular}

Tabel 3

Taraf Serap dan Rangking Jawaban Butir Pertanyaan Komponen Receiving

\begin{tabular}{|c|c|c|c|}
\hline No. Soal & Skor faktual & Taraf serap (prosentase) & Rangking \\
\hline 13 & 143 & $16.76 \%$ & 1 \\
\hline 11 & 136 & $15.94 \%$ & 2 \\
\hline 12 & 117 & $13.72 \%$ & 3 \\
\hline 8 & 113 & $13.25 \%$ & 4 \\
\hline 10 & 98 & $11.49 \%$ & 5 \\
\hline 7 & 96 & $11.25 \%$ & 6 \\
\hline 14 & 90 & $10.55 \%$ & 7 \\
\hline 9 & 60 & $7.04 \%$ & 8 \\
\hline Jumlah & 853 & 100 & \\
\hline
\end{tabular}


pernyataan nomor 5 dengan memperoleh taraf serap $5.51 \%$.

Berdasarkan tabel 2, pada komponen responding pernyataan nomor 13 mempunyai taraf serap terbesar dengan $16.76 \%$, sedangkan taraf serap terkecil ditempati pernyataan nomor 9 memperoleh taraf serap $7.04 \%$.

Berdasarkan tabel 3, pada sub komponen

Tabel 4

Taraf Serap dan Rangking Jawaban Butiran Pertanyataan Komponen Valuing

\begin{tabular}{cccc}
\hline No. Soal & Skor faktual & $\begin{array}{c}\text { Taraf serap } \\
\text { (prosentase) }\end{array}$ & Rangking \\
\hline 15 & 124 & $13.58 \%$ & 1 \\
\hline 16 & 121 & $13.25 \%$ & 2 \\
\hline 17 & 108 & $11.83 \%$ & 3 \\
\hline 18 & 98 & $10.73 \%$ & 4 \\
\hline 19 & 113 & $12.38 \%$ & 5 \\
\hline 20 & 131 & $14.35 \%$ & 6 \\
\hline 21 & 110 & $12.05 \%$ & 8 \\
\hline 22 & 108 & $11.83 \%$ & \\
\hline
\end{tabular}

Berdasarkan tabel 4, pada sub komponen valuing mempunyai dukungan terbesar terhadap terbentu-knya minat, dengan besar dukungan $35.35 \%$, kemudian peringkat kedua adalah sub komponen receiving sebesar $33.03 \%$, sedangkan dukungan terkecil ditempati sub komponen responding dengan dukungan sebesar $31.62 \%$. Untuk komponen receiving pernyataan nomor 15 mempunyai taraf serap terbesar dengan $13.58 \%$, sedangkan taraf serap terkecil ditempati pernyataan nomor 22 dengan memperoleh taraf serap $11.83 \%$.Selanjutnya akan penulis kemukakan besarnya skor faktual dari masing-masing sub komponen, hasilnya sebagai berikut:

mengetahui seberapa besar keadaan minat siswi SLTP yang tergabung di SSB Queen terhadap permainan sepak bola di Kota Bandung yang dihubungkan dengan faktor-faktor yang mempengaruhinya yang diantaranya dapat dilihat pada tabel berikut ini:

Tabel 5

Skor Faktual Terbentukannya Minat Berdasarkan Sub Komponen

\begin{tabular}{lccc}
\hline \multicolumn{1}{c}{ Faktor-faktor } & No Buir Soal & Besar dukungan & Prosentase \\
\hline Lingkungan & $11,16,19,24$ & 470 & $18.38 \%$ \\
\hline Diri pribadi & $1,7,12,15$ & 461 & $18.03 \%$ \\
\hline Guru/ Pelatih & $2,4,9,13$ & 431 & $16.86 \%$ \\
\hline Sarana/Prasarana & $21,21,22,23$ & 431 & $16.86 \%$ \\
\hline Teman & $6,8,14,23$ & 418 & $16.35 \%$ \\
\hline Program & $3,5,10,18$ & 346 & $13.52 \%$ \\
\hline
\end{tabular}

Tabel 6

Skor Faktual Terbentukannya Minat Berdasarkan Faktor Pendukung

\begin{tabular}{lccl}
\hline \multicolumn{1}{c}{ Faktor-faktor } & No Buir Soal & Besar dukungan & Prosentase \\
\hline Lingkungan & $11,16,19,24$ & 470 & $18.38 \%$ \\
\hline Diri pribadi & $1,7,12,15$ & 461 & $18.03 \%$ \\
\hline Guru/ Pelatih & $2,4,9,13$ & 431 & $16.86 \%$ \\
\hline Sarana/Prasarana & $21,21,22,23$ & 431 & $16.86 \%$ \\
\hline Teman & $6,8,14,23$ & 418 & $16.35 \%$ \\
\hline Program & $3,5,10,18$ & 346 & $13.52 \%$ \\
\hline & & 2557 & $100 \%$ \\
\hline
\end{tabular}


Berdasarkan tabel di atas, dapat penulis jelaskan bahwa faktor-faktor yang mempengaruhi minat siswi SLTP yang tergabung di SSB Queen terhadap permainan sepak bola di Kota Bandung adalah, pertama lingkungan dengan besar dukungan 18.38\%, kedua diri pribadi dengan besar dukungan $18.03 \%$, ketiga adalah guru/pelatih dan sarana/prasarana dengan besar dukungan $16,86 \%$, selanjutnya ke lima adalah teman dengan besar dukungan $16.35 \%$, dan yang terakhir adalah faktor program dengan besar dukungan $13.52 \%$.

\section{SIMPULAN}

Permainan sepak bola yang menjadi salah satu bagian dari mata pelajaran pendidikan jasmani, pada pelaksanaanya sangat diminati oleh para siswa; ini dibuktikan oleh besarnya minat siswi SLTP yang tergabung di SSB Queen terhadap permainan sepak bola di Kota Bandung sebesar 71.75\%. Minat siswi SLTP yang tergabung di SSB Queen terhadap permainan sepak bola di Kota Bandung berdasarkan sub komponen valuing (evaluasi) yaitu besar dukungan $35 \%$. Minat siswi SLTP yang tergabung di SSB Queen terhadap permainan sepak bola di Kota Bandung berdasarkan faktor-faktor dipengaruhi oleh faktor lingkungan dengan dukungan sebesar $18.38 \%$.

\section{REKOMENDASI}

Berdasarkan hasil dari penelitian, rekomendasi yang disarankan adalah agar lebih banyak SSB yang menampung siswa perempuan dalam kelompok sepak bolanya, karena pada kenyataannya banyak siswa perempuan yang memiliki minat untuk bermain sepakbola.

\section{DAFTAR RUJUKAN}

Ady, K. Y. (2016). Antara Pemain Depan Dengan Pemain Belakang Pada Siswa Yang Mengikuti Ekstrakurikuler Sepakbola Tahun Ajaran 2015/2016 Di Sma .... Jurnal Olahraga, 3(2), 65-75.

B, M. V. A., \& Subiyono, H. S. S. S. (2015). Journal Of Sport Science And Fitness. Journal Of Sport Sciences And Fitness, 4(2), 430-439.

Chepyator-Thomson, J. R., \& Ennis, C. D. (2017). Reproduction And Resistance To The Culture Of Femininity And Masculinity In Secondary School Physical Education. Research Quarterly For Exercise And Sport, 68(1), 89-99.

Dewandaru, P. (2012). Kemampuan Dasar Bermain Sepakbola Bagi Siswa Yang Mengikuti Ekstrakurikuler Sepakbola Di Smp Negeri 1 Srandakan Bantul. Jurnal Keterampilan, 6(5), 44-52.

Griffin, P. S. (2014). Girls' Participation Patterns In A Middle School Team Sports Unit. Journal Of Teaching In Physical Education, 4(1), 30-38.

Herwin. (2016). Diktat Pembelajaran Keterampilan Sepakbola Dasar. Universitas Negeri Yogyakarta.

Hidayat Nur, W. (2016). Pengaruh Permainan Target Terhadap Kemampuanshooting Dalam Permainan Sepakbola Pada Siswa Kelaskhusus Olahraga Di Sma N 2 Playen Gunungkidul. Jurnal Olahraga, $1(20), 54-62$.

Hurlock, E. B. (2013). Perkembangan Anak. Bandung : Erlangga.

Irianto, S. (2012). Pengembangan Tes Kecakapan “David Lee” Untuk Sekolah Sepakbola (Ssb) Kelompok Umur 14-15 Tahun. Universitas Negeri Yogyakarta.

Irwanto. (2014). Psikologi Umum : Buku Panduan Mahasiswa. Jakarta: Pt Gramedia Pustaka Utama.

Kokoti, J., Pomatahu, A. R., \& . R. (2015). Meningkatkan Kemampuan Lemparan Ke Dalam Pada Permainan Sepak Bola Melalui Metode Explicit Instruction Siswa Kelas Vii Smp N 2 Gorontalo. Kim Fakultas Ilmu-Ilmu Kesehatan Dan Keolahragaan, 3(3).

Komara, E. (2012). Metode Penelitian Karya Ilmiah. Bandung: Multazam.

Linda Rikard, G., \& Banville, D. (2016). High School Student Attitudes About Physical Education. Sport, Education And Society, 11(4), 385-400.

Lirgg, C. D. (2013). Effects Of Same-Sex Versus Coeducational Physical Education On The Self-Perceptions Of Middle And High School Students. Research Quarterly For Exercise And Sport, 64(3), 324-334. 
Markovits, A. S., \& Hellerman, S. L. (2013). Women's Soccer In The United States: Yet Another American "Exceptionalism." Soccer \& Society, 4(2-3), 14-29.

Pamungkas, G. (2016). Pengaruh Permainan Modifikasi Sepakbola Empat Gawang Terhadap Kesegaran Jasmani Siswa Putra Kelas V Di Sd Negeri Sinduadi 1,. Jurnal Olahraga, 19(22), 56-64.

Permadi, A. A. (2016). Pengaruh Model Latihan Fisik Dan Kecerdasan Emosi Terhadap Keterampilan Sepakbola. Edusentris, 3(2), 135-148.

Rustanto, D., \& Rustanto, S. (2013). Nilai-Nilai Sosial Dalam Permainan Sepakbola Pada Pendidikan Jasmani Di Kelas Vii Smp Negeri 14 Yogyakarta Tahun 2012/2013. Jurnal Olahraga, 4(3), 70-79. I

Surya. (2012). Psikologi. Bandung : Ikip.

Treanor, L., Graber, K., Housner, L., \& Wiegand, R. (2015). Middle School Students' Perceptions Of Coeducational And Same-Sex Physical Education Classes. Journal Of Teaching In Physical Education, 18(1), 43-56. 